\title{
In Search of a New Pragmatist Anthropology
}

\section{Emil Višňovský}

\section{OpenEdition}

\section{Journals}

Electronic version

URL: http://journals.openedition.org/ejpap/2202

DOI: 10.4000/ejpap.2202

ISSN: 2036-4091

\section{Publisher}

Associazione Pragma

\section{Electronic reference}

Emil Višňovský, «In Search of a New Pragmatist Anthropology », European Journal of Pragmatism and American Philosophy [Online], XII-2 | 2020, Online since 14 December 2020, connection on 15 December 2020. URL : http://journals.openedition.org/ejpap/2202 ; DOI : https://doi.org/10.4000/ ejpap.2202

This text was automatically generated on 15 December 2020.

\section{cc) (†) $\odot$}

Author retains copyright and grants the European Journal of Pragmatism and American Philosophy right of first publication with the work simultaneously licensed under a Creative Commons AttributionNonCommercial-NoDerivatives 4.0 International License. 


\title{
In Search of a New Pragmatist Anthropology
}

\author{
Emil Višňovský
}

\section{AUTHOR'S NOTE}

This work was supported by the Slovak Research and Development Agency under contract No. APVV-18-0103, "Paradigmatic Changes in the Understanding of Universe and Man from Philosophical, Theological, and Physical Perspectives."

\section{Introduction}

1 The influence of Richard Rorty has not faded since his demise more than a decade ago. Some of his works have been published posthumously (Rorty 2010; Rorty 2016), others have been republished in valuable collections (Voparil \& Bernstein 2010; Rorty 2014) and some of his unpublished work has already appeared too (Małecki \& Voparil 2020). ${ }^{1}$ Important international symposia have been held around the world (see e.g. Penelas \& Voparil 2014) ${ }^{2}$ and the Richard Rorty Society (RSS) was founded in 2014 "to promote study of the work and life of Richard Rorty (1931-2007), and to encourage and support scholarship and other writing inspired by and in the spirit of his work, across the disciplines." ${ }^{3}$ Last but not least, in addition to volume XXXII of The Library of Living Philosophers (Auxier \& Hahn 2010), a whole host of new monographs and anthologies provide analyses, interpretations and, to varying degrees, syntheses of Rorty's oeuvre and legacy. ${ }^{4}$ In this context, the recent monograph by Rosa Maria Calcaterra (2019) represents, in my view, a serious effort in the search of a new pragmatist anthropology.

Rorty's vision of philosophy differs entirely from the traditional one. Critical of the past it seeks new and original ways of breathing life and interest back into philosophy. In many respects his intentions and efforts were so radical that they were most often misunderstood at best or misrepresented at worst. Understanding him correctly is one 
of the tasks that still lies ahead of us Rortyans. In its own way Calcaterra's book serves this mission. In her efforts to shed greater clarity on the whole Rortyan philosophical mission she has picked out the key points of his project, such as the linguistic turn, new pragmatism, anti-representationalism, anti-foundationalism, anti-authoritarianism and anti-dualism in understanding relations between nature and culture. Comprehending what Rorty was attempting to achieve in philosophy is by no means an easy task. For instance, how can one put together his pluralistic, yet holistic style? Rorty's philosophy still needs explication and Calcaterra's book graciously fulfils this task in various ways.

\section{Moderate Rortyism}

Calcaterra's approach to Rorty is balanced and moderate rather than radical. She is cautious not to draw any ill-considered conclusions from his challenges. This is clear throughout her work in her attempts at blending pragmatism with analytic philosophy (or logical positivism), ${ }^{5}$ which is what her general strategy is aimed at. When she ascribes this strategy to Rorty, arguing for a permanent Carnapian instalment in his anti-metaphysical (and for that matter anti-foundationalist and antirepresentationalist) orientation, she makes explicit an aspect of Rorty that has somehow remained hidden. ${ }^{6}$ According to Calcaterra, Rorty had learned not only the limits of analytic philosophy and the need to transcend them, but also the crucial metaphilosophical lesson he subsequently built on by making linguistic practices the centre of his philosophizing. She describes this development in more detail when directing our attention to the fact that Russell and Wittgenstein as well as Ayer and Ryle, and indeed Carnap - going as far back as the 1930s - had revealed that "the problems of philosophy are problems of language"' and hence the need for the "linguistic turn." Simply put, the lesson was that we should start analysing language as a means of distinguishing philosophical pseudo-problems from meaningful ones.

Nonetheless, being a linguistic philosopher and being an analytic philosopher, and not of the Russell-Ayer-Carnap-Quine line but the early Wittgenstein-Ryle-Sellars-Davidson one, is not the same thing. It all depends on how we understand language. Thus Rorty not only distinguished between analytic and linguistic philosophy, but remained a linguistic philosopher who turned pragmatist along the James-Dewey-later Wittgenstein-Heidegger and Gadamer line, having understood that the crucial thing is how we understand language. And Chapter 1 of Calcaterra's work provides us with a proper account of the Rortyan route from "analytic philosophy to pragmatism and vice versa.""

5 Another example of Calcaterra's remarkable, non-radical Rortyan integrative approach is that she accepts Peirce (unlike Rorty) and tries to find a way of accommodating both, rather than juxtaposing them, as is traditional. She is able to defend Peirce against Rorty's claim that he is "the most Kantian of thinkers" because she sees that Peirce's project was headed beyond Kant. Her interpretation brings Peirce closer to Rorty than the latter was himself aware most of the time, for instance by reminding us of analogies between Peirce and Wittgenstein in Rorty's early papers. She also refers to Peirce's "logical socialism" as being close to Rorty's understanding of the sociality of rationality (Calcaterra 2019: 85-6). Moreover, in Chapter 6 Calcaterra conclusively claims that there are analogies between Peirce's tychism and Rorty's contingentism. 


\section{Linguistic Pragmatism and its Discontents}

I am inclined to consider Chapter 2 on Rorty's linguistic pragmatism the key chapter, as in it Calcaterra explains how misguided it is to consider it as "linguistic idealism." Human beings are natural linguistic beings and their linguistic practices are real social practices, as real as any non-human natural entities incorporated into these practices. Without linguistic practices there would be no human beings. They make us human.

One type of linguistic practice to which Calcaterra pays considerable attention is the practices of justification. These are the paradigmatic social practices of social communication - Rortyan conversation - in which humans exchange their vocabularies and create not only the space of reasons and arguments, but also the spaces of values, meanings and ethical intentions, in fact the whole space of culture in which, and through which, they live their lives as real cultural beings. Calcaterra brings together both the epistemic and ethical uses of language as a tool with application primarily in interhuman (intersubjective) relations rather than as a tool of representation in language-reality relationships. Humans invented language to convey to each other what they want to achieve - their intentions and aims - and what they will do vis-à-vis non-human reality, but not for the purposes of telling the latter anything. "Reality does not speak, only we, humans, do" is the Rortyan thesis for understanding language and its role in the human world (see Rorty 1989: 6). Only we humans have thoughts, intentions and vocabularies. Through the latter we express the former and describe all we encounter - which we call "reality." Creating the cultural space has nothing to do with linguistic idealism. "We simply acknowledge the coextension of language and reality, recognizing it as a natural prerogative of humankind, shown and justified by our cognitive and moral practices." (Calcaterra 2019: 23). There is no real relation or interaction between the human mind and the non-human world apart from and outside human practices, both linguistic and non-linguistic. Our mind, or brain even, has no relation to reality until we start acting as linguistic and physical beings, and in both cases as social beings. Our mind or brain does not function in these interactions/ practices as a mirror of reality; it functions as a tool which produces what are called representations. Calcaterra knows very well that every use of language entails interpretation and that this component "is not only present in classical pragmatism but it constitutes a decisive part of it," although it was "used in order to criticize the traditional 'spectatorial' or 'correspondentist' theories of knowledge and truth" (ibid.). Calcaterra, and Rorty, explain that asking whether language has anything in common with reality is like the nonsensical question of whether "wrenches wrench." Or, by analogy, the question which Dewey was solving: whether experience takes us away from nature or, conversely, makes us participate in it. The correct pragmatist response to both questions would seem to be that both language and experience are real parts of our human reality, and that is both natural as well as sociocultural. Through experience and language we have creative and potentially multifaceted transactions with originally non-human reality but also with the reality created by us humans. Here, unfortunately, Rorty seems to be at least as radically against his main hero Dewey as he was against Peirce. Calcaterra is well aware of this. She defends Rorty's linguistic pragmatism as a substantial contribution, but at the same time she indicates that it 
would be a mistake to counterpose it with Dewey's naturalistic conception of experience. Language does not exist in separation from experience and vice versa.

While Calcaterra concentrates on linguistic practices in her book, she is well aware that they are not the whole of reality. Language is a real form of human behaviour, but "cognitive and moral practices" and other human social practices are not exclusively linguistic. They include non-linguistic empirical and causal components such as direct non-verbal and non-discursive transactions with natural and social environments. Thus we can think of "non-linguistic practices" in addition to linguistic ones. If we do this, we should do so with the important caveat that distinguishing between something does not mean dividing it. ${ }^{8}$ In reality, both linguistic and non-linguistic practices have complex mutual transactions which have yet to be clarified. ${ }^{9}$ What seems clear is that linguistic practices serve as tools in human non-linguistic transactions with reality and even more so, according to Dewey, as the "tool of tools." In other words, to survive effectively in the natural environment humans have developed language as their tool, alongside other tools, for adapting and even transcending nature. It is no wonder that human linguistic practices produce "idealistic" things in relation to reality, i.e. projects, visions or utopias expressed in language that motivate and direct human actions.

Calcaterra indicates, though mostly "between the lines" rather than explicitly, that to suppose there can be dualism between linguistic and non-linguistic practices is hopeless. She invokes the works of Richard Bernstein, Joseph Margolis, Richard Shusterman, Thomas Alexander and Colin Koopman to indicate that humans are naturally physical, somatic beings. The Rortyan linguistic opposition to Deweyan experiential pragmatism must therefore be corrected. Linguistic practices are crucial but they are not primary and nor are they self-sufficient. In other words, language cannot eradicate or substitute experience, or vice versa. Culture cannot replace nature; they are coextensive. One cannot think without language, but non-linguistic interaction with reality is possible. Thinking is not the only way we relate to reality even though our relations obtain a qualitatively different level, i.e. a distinctively human level, through language. We can describe anything in language including experience; nonetheless, this does not make the non-linguistic linguistic.

The "experience or language" dichotomy is false and unfortunate. Rorty was right to stress language, but not at the expense of experience. He was right to reject the Cartesian notion of experience, but not the Deweyan one. To support Dewey here rather than Rorty does not mean supporting naturalistic metaphysics, which Rorty was opposed to. Language does not function when separated from experience, and experience does not function when separated from language. Human experience is linguistic, and human language entails experience. But this alliance between language and experience is pragmatist rather than analytic philosophical in conception. If this reading is correct, then to the extent that Rorty abandoned the concept of experience altogether, he has not, interestingly enough, moved beyond the analytic movement, mostly because he followed Davidson, according to Calcaterra (2019: 25). This reveals that his "linguistic pragmatism" is more Davidsonian than Deweyan, which is not the same. 


\section{Normativity and Pan-Linguisticism}

11 Rorty's philosophy of normativity is based on the idea of the anti-absolutism of norms. Normativity is socially created by humans; it is neither a natural kind nor a natural law. Here human is posited against nonhuman. So how can it be trustworthy if it is created by humans and is revisable? This is the issue because humans seem to have traditionally trusted some things that are immutable, stable, non-changeable, universal and steady if not eternal, ahistorical. But if the norms that humans devise for themselves are contingent, i.e. social, historical and dependable on human practices, then we encounter a problem here. The Rortyan solution to it, presented and advocated by Calcaterra, is not to be metaphysical. The criteria for devising and judging whether our social norms are "good" do not come from "above" or from a non-human authority. These criteria, like the norms themselves, come from our social practices and social values such as solidarity, empathy, hope, freedom, creativity and communication. That is, in sum, from humanism understood as "everything that encourages humanity, faith in our powers, human flourishing, and self-reliance rather than mistrust" and "everything that eliminates the evil inflicted on humans by humans" (Višňovský 2020: 16). But again, Calcaterra (2019: 38-9) rightly shows that Dewey's "naturalistic humanism" and Rorty's "deep humanism" differ because the latter insists on the "instrumental power of vocabularies," which she thinks is "very questionable" (ibid: 42). She goes on to "blame Rorty for having neglected the point that language itself is a part of experience," even though this "is not to contradict Rorty's rejection of foundationalist metaphysics" (ibid.: 43).

12 At this point Calcaterra agrees with Rorty that there is a causal link between language and reality, and Rorty of course agreed with Davidson on there being a causal link between beliefs and reality (ibid:: 44-6). This, again, as I see it, raises the tricky problem of the relations between linguistic practices, which function as vehicles of human cognitive beliefs as well as moral beliefs, and non-linguistic elements of reality. To my mind, it requires more detailed elaboration. If we ask questions like "Why do we think what we think?," or "Why do we speak as we speak?," the causal reply would be "Because reality determines that we think/speak as we do." However, in Rorty's case this is problematic since according to his conception of linguistic practice the reply should be: "Because our peers as linguistic agents make/persuade us to think/speak as we do." In other words, through social communication, the linguistic practice of members of our community influence other language users to think or speak as they do, and this relationship is based on understanding the meanings and norms of linguistic practices rather than on the causal operation of non-linguistic entities. Fullyfledged pragmatism is not a kind of pan-linguisticism, not even the Rortyan one. For it to be one, it would have to include a better understanding of relations between linguistic and non-linguistic transactions than anyone has developed so far. In fact, the label "linguistic pragmatism" is one-sided and insufficient owing to the singular focus on linguistic practices in abstraction from non-linguistic ones, as if the latter did not exist. But they do exist and they pose a problem regarding their relations, causal or otherwise, to linguistic practices. 


\section{The Concept of Human}

13 Finally, at the centre of Calcaterra's work is Rorty's key philosophical issue: understanding humans. Who are we humans? According to Rorty there is no nonhuman or supra-human authority that can answer this question for us; we humans are the only ones who care both about the question and the answer. According to Rorty's ethnocentrism, we are naturally cultural beings who cannot escape our culture as it is the creation of our community. We cannot escape our community nor its forms of life, including social practices, both linguistic and non-linguistic. Being cultural beings does not exclude us from among the creatures of nature, that is, the biological, physical, somatic beings who engage in transactions with the natural environment, as Dewey and other classical pragmatists have underscored. There is no culture without nature and nor is there culture without language. Both culture and language have transformative powers. Our human history is, indisputably, the history of "influential metaphors" or "linguistic history" (Calcaterra 2019: 9, 84, 92, 103). Changing vocabularies, inventing new ways of speaking, transforming linguistic and communicative practices obviously all lead to changes in behaviour not just in beliefs and mindsets. Rorty put his trust most of all in creativity of all kinds of linguistic practices and his social hope was "finding better versions of ourselves" (ibid.: 66). This was another reason why he valued imagination over knowledge as representation. $\mathrm{He}$ did not think our genuine human task lay in copying reality, obeying non-human authorities, looking for ahistorical (metaphysical) necessities and obtaining them; rather, because we are self-creative and self-interpretive beings, we should, and indeed could, do nothing more than produce better self-descriptions that might lead us to a better human future. In other words, we are creative subjects mutually responsible to ourselves. We "should find a way to free ourselves from the picture of the human being as responsible to something 'non-human,' including the notion of 'Objective Reality' that governs foundational epistemology and constantly traps our theoretical efforts" (ibid.: 116).

14 Calcaterra adeptly portrays (and supports) this Rortyan notion of human subjectivity as anti-essentialist (anti-Cartesian and anti-Kantian), that is, inter-subjective, social, historical, relational, pluralistic and contingent. She ably combines its narrative character with Humean naturalism while still reproaching Rorty for "overlooking the biological level of such a narrative model" and "focusing on the social-ethical side" (ibid.: 89-91). Such a conception would be unthinkable without the cultural mission of philosophy itself, consisting not only in cultural criticism but in its edifying and therapeutic functions. Calcaterra writes, "Philosophy is, to his [Rorty's] eyes, more an art than a scientific discipline: a cultural expression that resembles self-creative activities more than those which concern the inquiry into the physical world" (ibid: 92). Of course, anything that depends on human subjectivity is not guaranteed by an "objective authority" and is simply human, that is, contingent: "Renouncing the idea of an intrinsic, universal and predetermined human nature, he [Rorty] affirms that each person is a web of beliefs, behaviors and desires that are the result of a series of contingent factors, such as family and school education, cultural tradition and linguistic forms." (Ibid.: 93).

15 I take it that Calcaterra's ultimate ambition is to draw on Rorty to outline a new pragmatist anthropology, as she says in Chapter 6, the last in the book. She restates 
that this cannot be done without referring to Dewey's conception of experience nor Rorty's conception of the contingent character of normativity as implied in linguistic practices. But these practices should not be "conceived as a key factor in the interactions with the physical-natural and social environment within which the vital needs of human beings take place and, as a consequence," but rather as the "tool of tools" (ibid.: 112). She suggests that neither the classical pragmatist theory of habits and the neopragmatist theory of norms - or the Deweyan conception of experience and the Rortyan conception of language - are incompatible (ibid.: 120). This seems promising, but we should go further by reconstructing Dewey's understanding of language (Dreon 2014) and Rorty's understanding of experience (Timm 2019).

\section{Conclusion}

Calcaterra's philosophy can be labelled "integrative" given its balanced efforts to avoid sharp contrasts between the analytic school and pragmatism, and old and new pragmatisms. It is a philosophy aimed at integrating science and the arts, language and experience, descriptive and normative, irony and solidarity, emotion and reason, ethics and aesthetics, logic and behaviour, contingency and normativity, and so on. The strategy is to "transcend" any kind of dualism. Thanks to this Calcaterra ranks among distinguished contemporary European pragmatists. In particular she has become one of the most respected international Rortyan scholars. She advocates a non-reductive naturalism, one of the most promising conceptions of a new pragmatist anthropology, which is urgently needed in the current era of humanity in crisis.

\section{BIBLIOGRAPHY}

AUXIER Randall E. \& Lewis Edwin HAHN (eds.), (2010), The Philosophy of Richard Rorty, Chicago, Open Court.

Calcaterra Rosa M. (ed.), (2011), New Perspectives on Pragmatism and Analytic Philosophy, Amsterdam and New York, Rodopi.

CALCATERRA Rosa M., (2019), Contingency and Normativity: The Challenges of Richard Rorty, Leiden/ Boston, Brill/Rodopi.

DREON Roberta, (2014), “Dewey on Language: Elements for a Non-Dualistic Approach,” European Journal of Pragmatism and American Philosophy, 6, 2. Online: [https://journals.openedition.org/ ejpap/309].

GASCOIGNE Neil, (2008), Richard Rorty, Cambridge, Polity Press.

GRÖSCHNER Alexander, KOOPMAN Colin \& Mike SANDBOTHE (eds.), (2013), Richard Rorty. From Pragmatist Philosophy to Cultural Politics, London, Bloomsbury.

GROSS Neil, (2008), Richard Rorty. The Making of American Philosopher, Chicago, The University of Chicago Press. 
KUIPERS Ronald A., (2013), Richard Rorty, London, Bloomsbury.

MALACHOWSKI Alan (ed.), (2020), A Companion to Rorty, Oxford, Wiley-Blackwell.

MAŁECKI Wojciech P. \& Christopher J. voPARIL (eds.), (2020), On Philosophy and Philosophers.

Unpublished Papers, 1960-2000, Cambridge, Cambridge University Press.

PENELAS Federico \& Christopher J. VOPARIL, (2014), "Introduction to International Symposium on Richard Rorty," Contemporary Pragmatism, 11 (1), 1-4.

RORTY Richard, (1989), Contingency, Irony, and Solidarity, Cambridge, Cambridge University Press.

RORTY Richard, (2010), An Ethics for Today: Finding Common Ground Between Philosophy and Religion, New York, Columbia University Press.

RORTY Richard, (2014), Mind, Language, and Metaphilosophy. Early Philosophical Papers, Stephen Leach \& James Tartaglia (eds.), Cambridge, Cambridge University Press.

RORTY Richard, (2016), Philosophy as Poetry, Charlottesville \& London, University of Virginia Press.

SANDBOTHE Mike, (2004), “The Pragmatic Twist of the Linguistic Turn,” in William Eggington \&

Mike Sandbothe (eds.), The Pragmatic Turn in Philosophy: Contemporary Engagements between Analytic and Continental Thought, Albany, State University of New York Press, 67-92.

SCHULENBERG Ulf, (2015), Romanticism and Pragmatism: Richard Rorty and the Idea of a Poeticized Culture, New York, Palgrave Macmillan.

TIMM Tobias, (2019), Richard Rorty and the Problem of Postmodern Experience. A Reconstruction, Lanham, Lexington Books.

VIŠŇOVSKÝ Emil, (2015), Richard Rorty a zrkadlo filozofie [Richard Rorty and the Mirror of Philosophy], Bratislava, Kalligram.

VIŠŇOVsKÝ Emil, (2018), “Action, Practice, and Theory: Toward Pragmatist Philosophical Framing of Practice Theory," in Anders Buch \& Ted Schatzki (eds.), Questions of Practice in Philosophy and Social Theory, New York \& London, Routledge, 31-48.

VIŠŇOVSKÝ Emil, (2020), “Rorty's Humanism. Making it Explicit," European Journal of Pragmatism and American Philosophy, 12 (1). Online: [https://journals.openedition.org/ejpap/1878].

VIŠŇOVSKÝ Emil \& Egon GÁL, (2011), “K Rortyho miestu v dejinách západnej filozofie” [On Rorty’s Place in the History of Western Philosophy], Filozofia, 66 (10), 957-62.

VOPARIL Christopher J. \& Richard J. BERNSTEIN (eds.), (2010), The Rorty Reader, Oxford, WileyBlackwell.

\section{NOTES}

1. What I would particularly like to see republished in a single volume are Rorty's interviews and book reviews, or at least a substantial selection of them. This could be done in a reasonable period of time, whereas the critical edition of Collected Works of Richard Rorty, if there is such a project, probably awaits another generation of scholars.

2. A small local conference commemorating Rorty's posthumous 80 th birthday was held by the Slovak Philosophical Association in Bratislava (see Višňovský \& Gál 2011).

3. See [https://richardrortysociety.org]. So far two international conferences have been held by the RSS, in 2016 and 2019. 
4. Of these I would like to list Gascoigne (2008), Kuipers (2013), Gröschner, Koopman \& Sandbothe (2013), Schulenberg (2015) and Malachowski (2020). Višňovský (2015) has similar intentions.

5. Her understanding of "analytic philosophy" extends very broadly to all "post-Wittgensteinian philosophies" (see Calcaterra 2011).

6. Rorty's attitude towards analytic philosophy was for the most part critical and dismissive.

7. For the difference between the pragmatist (and Rortyan) linguistic turn and other linguistic turns see Sandbothe (2004).

8. I outlined the distinction between linguistic and non-linguistic practices in Višňovský (2018).

9. It would require, to my mind, the integration of Dewey's and Rorty's conceptions of human social practices. Robert Brandom has travelled farthest in this direction, but he is still immersed more in linguistic practices than in the transactions between the two.

\section{AUTHOR}

\section{EMIL VIŠŇOVSKÝ}

Comenius University

emil.visnovsky[at]uniba.sk 